\title{
Effects of Coconut Fibers on Mechanical Properties of Concrete
}

\author{
Dharmik Patil $^{1}$, Mihir Vanmali ${ }^{2}$, Jayashree Sonar ${ }^{3}$, Pranay Tandel ${ }^{4}$, Mrs. Swati Dhurve ${ }^{5}$ \\ ${ }^{1234}$ B.E. Student, Department of Civil Engineering, University of Mumbai, Palghar \\ ${ }^{5}$ Assistant professor, St. John College of Engineering and Management, Palghar
}

Received on: 15 April,2021, Revised on: 15 May,2021, Published on: 16 May, 2021

\begin{abstract}
Coconut fiber is treated as natural fiber. Natural fibers are those fibre which are environment friendly, pollution free and does not have any bad effect on climate. Every year there is ample amount of wastage of natural fibre. If these fibers used as a construction material it could save the bio-reserves. They Acts as green construction material. Amongst all natural fibres, coconut fibre is the fibre which has the better physical and chemical property also it is renewable, cheap, resistance to thermal conductivity, more durable, highest toughness, most ductile then other natural fibre. The problem of high rate of water absorption of the fibre could be reduced by coating the fibres with oil. This study aimed at analyzing the variation in strength of coconut fiber (oil coated fibres) reinforced concrete at varying fibre contents and fiber size to compare it with that of conventional concrete. The addition of coconut fibre improves various mechanical properties of concrete. Addition of coconut fibre improves the compressive strength and split tensile strength of concrete, they also formed good bonding in concrete. The experiment was conducted on concrete with the addition of 3 mix proportions $(1 \%, 2 \%, 3 \%)$ by the weight of cement. The compressive strength and split tensile strength of cured concrete evaluated for 7 days and 28 days. The study found the optimum fibre content to be $1 \%$ (by the weight of the cement). This result shows coconut fibre can be used in construction.
\end{abstract}

\section{Keywords- Effects, Coconut Fibres, Proportions}

\section{I- INTRODUCTION}

$\mathbf{T}$ he development of construction industry is upgrading in two major ways. One of the way is the development of construction techniques, such as using automated tools in construction and the other is the advancement in high-performance construction materials, such as the introduction of high strength concrete. Among these high performance materials, fibre reinforced concrete (FRC) is gradually gaining acceptance from civil engineers. In recent years, research and development of fibres and matrix materials and fabrication process related to construction industry have grown rapidly. Their advantages over other construction materials are their high tensile strength to weight ratio, ability to be moulded into various shapes and potential resistance to environmental conditions, resulting in potentially low maintenance cost. These properties make FRC composite a good alternative for innovative construction. Their application in construction includes both upgrading existing structures as well as new buildings, which can apply to various types of structure like offshore platforms, buildings and bridges.

A major obstacles towards development of high performance concrete using steel fibres is the high costs involved, availability and also problem of corrosion. The awareness of increasing cost of steel is rising day by day because of which making a structure or even a small load bearing structure is quite difficult nowadays for a budget projects. Coconut fibre being the most ductile among all natural fibres has the potential to be used as a reinforcement material in concrete. Coconut fibre is extracted from the outer shell of a coconut. The common name, scientific name and plant family of coconut fibre is Coir, Cocos nucifera and Arecaceae (Palm) respectively. There are two types of coconut fibres, brown fibre extracted from matured coconuts and white fibres extracted from immature coconuts. Coconut fibres are stiff and tough and have low thermal conductivity. Coconut fibres are commercial available in three forms, 


\section{International Journal of Innovations in Engineering and Science, www.ijies.net}

namely bristle (long fibres), mattress (relatively short) and decorticated (mixed fibres). It is biodegradable so the impact on environment will be minimal. This is also a way to dispose off the fibres which are derived as waste materials from coir based manufacturing units to produce high strength materials .They are also nonabrasive in nature, cheap and easily available.

The primary aim of this project study was to identify the improvement in strength characteristics of concrete with the addition of oil coated coconut fibre. In the study, coconut fibre is added to concrete and Plain Cement Concrete (PCC) is used as reference to study its effect on compressive and tensile strength properties and also in reduction in cracking. Fibre is coated with oil so as to decrease the water absorption. Some of the advantages being observed are low-cost, low density, reasonable specific strength, good thermal insulation, reduced wear and ability to be recycled with minimal impact on environment. Thus in addition to the enhancement in the physical properties of concrete, it turns out to be a sustainable waste management technique.

\section{II- OBJECTIVES}

- To study the basic materials which are used in concrete.

- To study the tests performed on concrete as well as the materials used in it.

- To use the waste coconut strands as a natural fibre in the concrete.

- To check the Engineering properties of Coconut Fibre Reinforced Concrete. (Compressive test, etc.)

- To find out the mechanical properties of Coconut Fibre Reinforced Concrete (CFRC) and to compare it with the conventional concrete.

\section{III- MATERIALS AND TESTS}

For current project work various materials like Coarse aggregate and fine aggregate are collected. We conducted various tests on the above mentioned materials in laboratory.

\subsection{Cement}

Ultratech cement PPC 43 procured from single source was used. Physical properties of which are tested in the laboratory and tabulated in Table 1.

Table 1: Physical properties of cement

\begin{tabular}{|c|c|}
\hline Properties & Value Obtained \\
\hline Standard consistency of cement & $34 \%$ \\
\hline Initial setting time & $70 \mathrm{~min}$ \\
\hline Final setting time & $360 \mathrm{~min}$ \\
\hline Specific gravity & $2.90 \mathrm{~g} / \mathrm{cc}$ \\
\hline
\end{tabular}

Coarse aggregate having nominal size $20 \mathrm{~mm}$ were used and different taste were performed and the result are tabulated as below.

Table 2: Physical properties of coarse aggregates

\begin{tabular}{|l|c|}
\hline \multicolumn{1}{|c|}{ Properties } & Value obtained \\
\hline Specific gravity & 2.74 \\
\hline Fineness modulus & 7.1 \\
\hline Water absorption & 3.07 \\
\hline
\end{tabular}

\subsection{Fine Aggregate}

Good quality zone-I fine aggregate were used. The different tests for physical properties of fine aggregate are carried out in the laboratory and results are tabulated below.

Table 3: Physical properties of fine aggregates

\begin{tabular}{|l|c|}
\hline \multicolumn{1}{|c|}{ Properties } & Value Obtained \\
\hline Specific gravity & 2.74 \\
\hline Fineness modulus & 3.5 \\
\hline Water absorption & $2.04 \%$ \\
\hline
\end{tabular}

\subsection{Coconut Fibres}

Coconut fibre as a waste material procured from coconut vendor in local market but can also be procured from coconut oil manufacturing unit for large scale use. They are properly washed before use. The fibres were treated with coconut oil. The oil was applied on fibres and then sun dries for 24 hours. The coconut fibres strands are basically cutted into two sizes that are $3 \mathrm{~cm}$ and $6 \mathrm{~cm}$ in length. The fibres used in this research are mix fibre that is combination of both $3 \mathrm{~cm}$ and $6 \mathrm{~cm}$ fibre at once. The amount of fibre content adopted is $1 \%, 2 \%$ and $3 \%$ of cement.

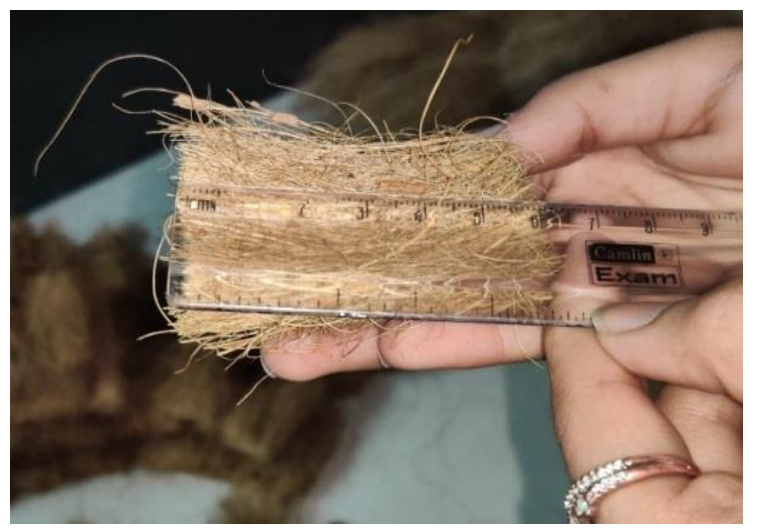

\subsection{Coarse Aggregate}




\section{International Journal of Innovations in Engineering and Science, www.ijies.net}

\section{IV- EXPERIMENTAL WORK}

We have made an attempt to design concrete of grade M25. The mix design has been carried out for the material details specified. The investigation was done by taking $1 \%, 2 \%$ and $3 \%$ (by the weight of cement) of $3 \mathrm{~cm}$ and $6 \mathrm{~cm}$ coconut fibre in concrete mix. The no. of cubes and cylinders are casted for the present study are listed in the table 4. Casting and curing of cubes and cylinders are done as per the standard procedure. After curing for 7 days and 28 days, we have performed compressive strength test on concrete cubes and split tensile strength on concrete cylinders.

Table 4- The experimental work for M25

\begin{tabular}{|c|c|c|c|c|}
\hline $\begin{array}{l}\mathrm{Sr} \\
. \mathrm{no}\end{array}$ & $\begin{array}{c}\text { Speci } \\
\text { men }\end{array}$ & $\begin{array}{l}\text { Specimen } \\
\text { Dimension }\end{array}$ & $\begin{array}{c}\text { Sample } \\
\text { Description } \\
\text { (Concrete With) }\end{array}$ & $\begin{array}{l}\text { Tot } \\
\text { al } \\
\text { No. }\end{array}$ \\
\hline \multirow{4}{*}{1} & \multirow{4}{*}{ Cubes } & \multirow{4}{*}{$\begin{array}{l}150 \mathrm{~mm} \mathrm{x} \\
150 \mathrm{~mm} \mathrm{x} \\
150 \mathrm{~mm}\end{array}$} & $\begin{array}{l}\text { without } \\
\text { coconut fibre }\end{array}$ & 6 \\
\hline & & & $\begin{array}{c}\text { with } 1 \% \\
\text { coconut fibre }\end{array}$ & 6 \\
\hline & & & $\begin{array}{c}\text { with } 2 \% \\
\text { coconut fibre }\end{array}$ & 6 \\
\hline & & & $\begin{array}{c}\text { with } 3 \% \\
\text { coconut fibre }\end{array}$ & 6 \\
\hline \multirow{4}{*}{2} & \multirow{4}{*}{$\begin{array}{l}\text { Cylin } \\
\text { der }\end{array}$} & \multirow{4}{*}{$\begin{array}{l}150 \mathrm{~mm} \mathrm{x} \\
300 \mathrm{~mm}\end{array}$} & $\begin{array}{c}\text { without } \\
\text { coconut fibre }\end{array}$ & 6 \\
\hline & & & $\begin{array}{c}\text { with } 1 \% \\
\text { coconut fibre }\end{array}$ & 6 \\
\hline & & & $\begin{array}{c}\text { with } 2 \% \\
\text { coconut fibre }\end{array}$ & 6 \\
\hline & & & $\begin{array}{c}\text { with } 3 \% \\
\text { coconut fibre }\end{array}$ & 6 \\
\hline
\end{tabular}

\section{V- RESULTS}

Samples were tested after 7days and 28days and all the data and results are given in charts. The test result obtained from Compressive strength test and Tensile strength test for concrete are analyzed graphically. In this section, average compressive strength for 7 days and 28 days of concrete have been compared between conventional concrete and fibre reinforced concrete. Similarly, the procedure was carried out for tensile strength of concrete.

\subsection{Compressive Strength}

Compressive Strength is defined as resistance of concrete to axial loading. Cubes were placed in Compressive Testing Machine (CTM), and load was applied. The readings were recorded upto final crack of the cube and compressive strength was calculated. The results of Compressive strength are shown in Table. Calculations :Compressive Strength =Maximum load/Cross Sectional Area =P/A.
Table 5-Compressive strength of Concrete.

\begin{tabular}{|c|c|c|c|c|}
\hline $\begin{array}{c}\text { Sr } \\
\text { no }\end{array}$ & $\begin{array}{l}\text { Fiber } \\
\text { Added }(\%)\end{array}$ & $\begin{array}{c}\text { w/c } \\
\text { ratio }\end{array}$ & $\begin{array}{c}7 \text { days } \\
(\mathrm{n} / \mathrm{mm} 2)\end{array}$ & $\begin{array}{c}28 \text { days } \\
(\mathrm{n} / \mathrm{mm} 2)\end{array}$ \\
\hline 1. & $0 \%$ & 0.48 & 17.22 & 28.20 \\
\hline 2. & $1 \%$ & 0.48 & 17.30 & 28.31 \\
\hline 3. & $2 \%$ & 0.48 & 15.93 & 26.17 \\
\hline 4. & $3 \%$ & 0.48 & 13.76 & 24.31 \\
\hline
\end{tabular}

Chart 1: Graph showing variation of compressive strength at varying percentages of fibre

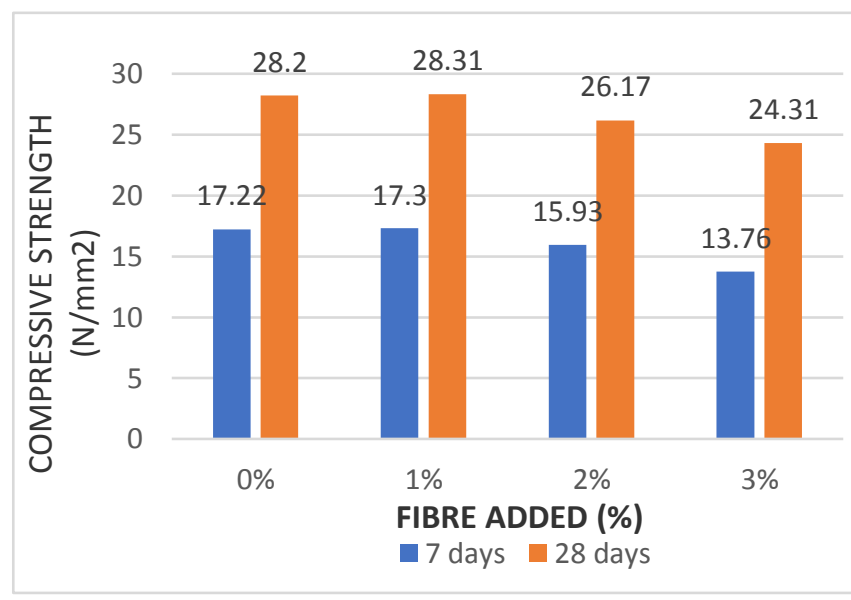

Chart 2: Graph 2 showing variation of compressive strength at varying percentages of fibre

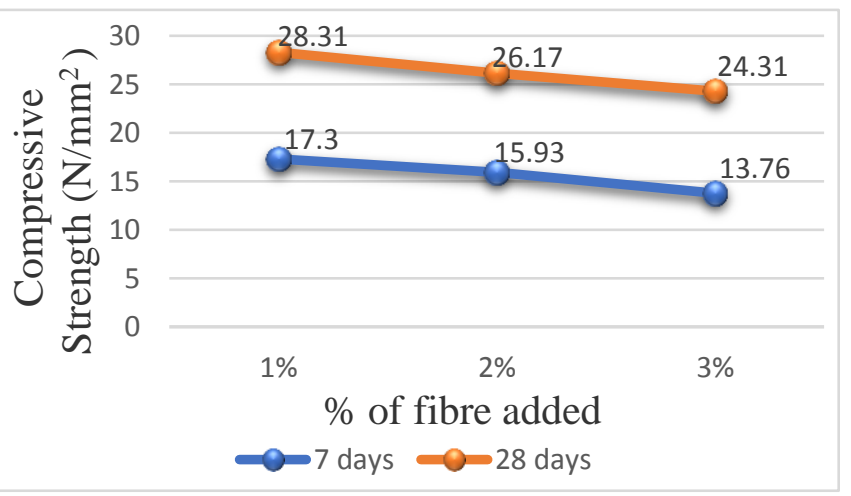

The compressive strength test was conducted on the cubes with varying fibre content $(0 \%, 1 \%, 2 \%, 3 \%)$. From the graph that shows the variation of compressive strength of concrete at varying percentage of fibre, it was found that compressive strength of concrete decreases with an increase in fibre content.

\subsection{Spilt Tensile Strength}

Cylinders were placed in Compressive Testing Machine (CTM) and load was applied. The readings were 


\section{International Journal of Innovations in Engineering and Science, www.ijies.net}

recorded up to the final crack of the cylinder and split tensile strength was calculated. Cylinders are calculated by using the formula PL/3.14* DL, where $\mathrm{P}=\mathrm{Load}$, $\mathrm{L}=$ clear span length, $\mathrm{D}=$ Diameter of the specimen. The values were shown in

\begin{tabular}{|c|c|c|c|c|}
\hline $\begin{array}{l}\text { Sr } \\
. n o\end{array}$ & $\begin{array}{l}\text { Fiber } \\
\text { Added } \\
(\%)\end{array}$ & $\begin{array}{c}\text { w/c } \\
\text { ratio }\end{array}$ & $\begin{array}{l}7 \text { days } \\
(\mathrm{n} / \mathrm{mm} 2)\end{array}$ & $\begin{array}{l}28 \text { days } \\
(\mathrm{n} / \mathrm{mm} 2)\end{array}$ \\
\hline 1. & $0 \%$ & 0.48 & 1.79 & 3.33 \\
\hline 2. & $1 \%$ & 0.48 & 1.88 & 3.45 \\
\hline 3. & $2 \%$ & 0.48 & 1.55 & 2.31 \\
\hline 4. & $3 \%$ & 0.48 & 1.28 & 2.19 \\
\hline
\end{tabular}

Chart 3: Graph showing variation of split tensile strength at varying percentages of fibre

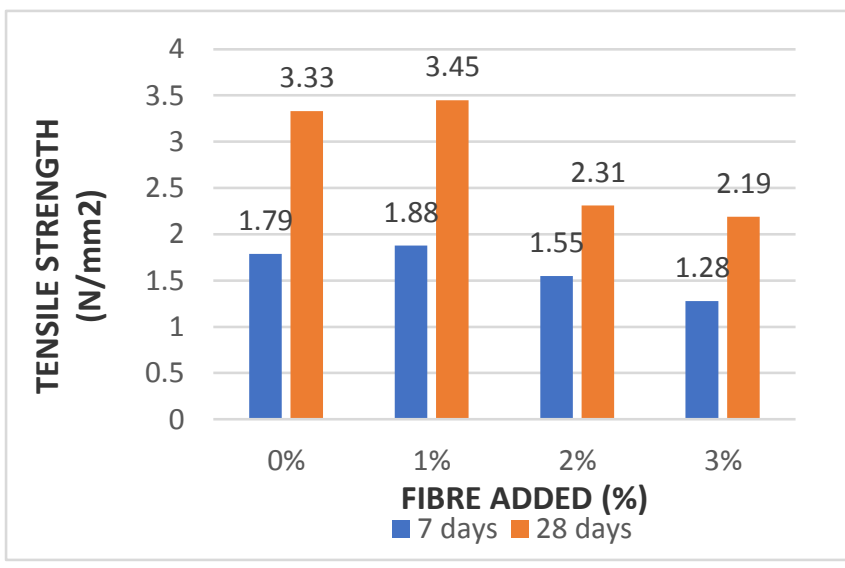

Chart 4: Graph 2 showing variation of split tensile strength at varying percentages of fibre

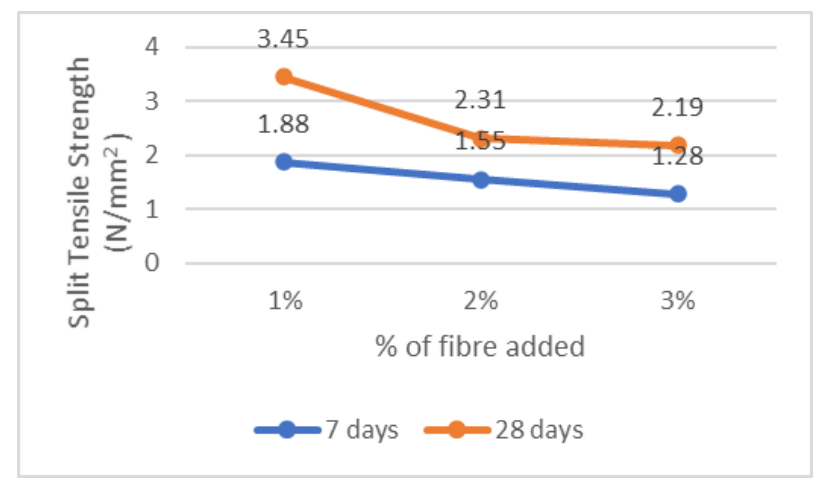

The split tensile strength test was conducted on the cylinder with varying fibre content $(0 \%, 1 \%, 2 \%, 3 \%)$. From the graph that shows variation in tensile strength of concrete with change in fibre content, it was found that the tensile strength of concrete decreases with an increase in the fibre content of the concrete mix.

\section{VI- CONCLUSIONS}

While testing the specimen, the plain cement concrete specimens have shown a typical crack propagation pattern but when CFRC specimen were tested, cracks gets ceased which results into the ductile behavior of CFRC. Coconut fiber are coated with oil which impact the reduction in water absorption and increase in shearing strength. At $1 \%$ addition of coconut fibre in concrete increases compressive strength and tensile strength of concrete. However, the compressive strength and tensile strength decreased on further fibre addition and it can be concluded that the fibre should not be used beyond $1 \%$. The addition of coconut-fibres significantly improved many of the engineering properties of the concrete, notably torsion, toughness and tensile strength. The ability to resist cracking and spalling were also enhanced. However, the addition of fibres adversely affected the compressive strength, as expected, due to difficulties in compaction which consequently led to increase of voids.

\section{REFERENCES}

[1] IS 456-2000 Plain and reinforced concrete- code of practice. IS 383-1970 for fine and coarse aggregate.

[2] Karan p. Pujari, Nikhil D. Dhodiya, Mohitsingh, H. Chandel, Pawan N Bari, Swati R. Dhurve, Use of Plastic Waste in paver Block, International Journal of Research in Engineering, March2020

[3] Bhuvnesh Gawad, Swati Dhurve Study of biotechnology for waste water treatment, SSRG international journal of civil engineering, volume 7, issue 3, March 2020.

[4] D.M. Parbhane, S.B. Shinde, JNEC, Aurangabad, Maharashtra, India, Strength Properties of Coir Fiber Concrete. International Journal of Architecture (IJA), December 2019.

[5] V. Sai Uday, B.Ajitha JNTUA College of Engineering, Ananthapuram, AP, India, Concrete Reinforced with Coconut Fibres. International Journal of Engineering Science and Computing, April 2017.

[6] S. Sastha Arumuga Pandi, S. Yamini Roja, G. Jenitha, K. Alagusankareswari, Experimental Study on Behavior of Coir Fiber Reinforced Concrete. International Journal of Civil Engineering and Technology (IJCIET), February 2017.

[7] Shaikh Mohd Shadab Mohd Shafi, Siddiqui Saquib Masood Mouzzam, Hamza Sayyed Hasham Ali, Shaikh Shamsuddoha Mohd Umar, Anjuman-I-Islam's Kalsekar Technical Campus, "Effect of coconut fibre in concrete to improve the workability by incorporating an admixture". 
Vol. 6, No. 3, 2021, PP. 01-05

International Journal of Innovations in Engineering and Science, www.ijies.net

Year 2016.

[8] Kshitija Nadgouda, Sardar Patel College of Engineering, Andheri, Mumbai, Coconut Fibre Reinforced Concrete. International Journal of Mechanical And Production Engineering, Jan.-2015.

[9] Bhuvanesh Gawad, "Concrete Mix Proportioning: A Short Note", Journal of Environmental Science, Computer Science and Engineering \& Technology 5(3): June 2016, Pages 262-266.

[10] Aditya Tom, Anushree S, Diya Maria Varghese, Jerin Antony, Department of Civil Engineering Amal Jyothi College of Engineering Kanjirappally, "Coconut fibre reinforced concrete", April 2014.

[11] Dhandhania VA and Sawant S D.K.T.E. Society's Textile \& Engineering Institute, Ichalkaranji, India, "Coir Fiber Reinforced Concrete". Journal of Textile Science \& Engineering, 2014.

[12] Bhuvanesh Gawad, Swati Dhurve, "Health Safety and Risk Management in Residential Building", International Journal for Scientific Research \& Development, Volume 8, Issue 12, 2021, Pages 101-106.

[13] Majid Ali, Structure Design Section, National Engineering Services Pakistan (NESPAK) Islamabad Office, Pakistan, "Coconut fibre: A versatile material and its applications in engineering". Journal of Civil Engineering and Construction Technology,Year September2011. 